\title{
Overexpression of Id protein inhibits the muscle differentiation program: in vivo association of Id with E2A proteins
}

\author{
Yale Jen, Harold Weintraub, ${ }^{1}$ and Robert Benezra \\ Department of Cell Biology, Memorial Sloan Kettering Cancer Center, New York, New York 10021 USA; ${ }^{1}$ Department of \\ Genetics, Fred Hutchinson Cancer Center, Seattle, Washington 98104 USA
}

\begin{abstract}
The helix-loop-helix (HLH) protein Id lacks the basic DNA-binding domain common to this class of proteins. In vitro experiments suggested that Id could associate tightly with two other HLH proteins encoded by the E2A gene, E12 and E47 (referred to here collectively as E proteins) and prevent their binding to a sequence present in the muscle creatine kinase (MCK) enhancer either as homo-oligomers or hetero-oligomers with MyoD. In this report we present evidence for the in vivo roles of Id and E proteins: (1) Id and E proteins cofractionate and coimmunoprecipitate in whole-cell extracts prepared from myoblasts; (2) the loss of Id protein observed during the conversion of proliferating myoblasts into mature myotubes correlates with the formation of $\mathrm{MyOD} / \mathrm{E}$ hetero-oligomeric complexes in whole-cell extracts (these complexes do not form when purified Id protein is added to the extracts); and (3) stable overexpression of Id mRNA and protein in the C2C12 muscle cell line inhibits differentiation in these cells $16 \mathrm{hr}$ postinduction. The myotubes that do eventually form $48 \mathrm{hr}$ postinduction have no detectable Id protein in the nucleus despite the persistence of exogenous Id mRNA. These data support a model in which Id can inhibit muscle cell differentiation by associating with $\mathrm{E}$ proteins and preventing them from forming active hetero-oligomeric complexes with the muscle determination gene products.
\end{abstract}

[Key Words: Id protein; overexpression; helix-loop-helix; E proteins; muscle differentiation]

Received September 13, 1991; revised version accepted May 27, 1992.

It is now well established that helix-loop-helix (HLH) proteins play important roles in cell-type-specific transcription. Expression of MyoD, for example, can activate a battery of muscle-specific genes in response to the correct environmental stimuli (Davis et al. 1987). The achaete-scute gene complex is required for neuroblast determination in the central and peripheral nervous systems of Drosophila (Cabrera et al. 1987; Villares and Cabrera 1987; Gonzalez et al. 1989). Also, products of the E2A and E2-2 genes appear to regulate immunoglobulin expression in B cells (Murre et al. 1989a; Henthorn et al. 1990; Schlissel et al. 1991). The functional repertoire of these proteins is greatly expanded by the observation that these proteins form hetero-oligomeric species in vitro, as these complexes bind to DNA with altered affinities (Murre et al. 1989a,b; Davis et al. 1990) and sequence preferences (Blackwell and Weintraub 1990) relative to their homo-oligomeric counterparts. Furthermore, the inhibition of DNA binding of various HLH proteins in vitro by their association with the inhibitory HLH protein Idl, which lacks the basic DNA-binding domain (Benezra et al. 1990), provides the cell with another potential level of regulation.

Three members of the Id family have been identified so far in the mouse: Id1, Id2 (Sun et al. 1991), and
HLH462.3 (Christy et al. 1991), also referred to as Id3. All three members have a high degree of conservation in the HLH domain and have been shown to inhibit E proteins or MyoD/E complexes from binding DNA in vitro. The Drosophila homolog of Id, called extramachrochate (emc), which antagonizes the activity of T4 (scute) genetically, contains striking homology to the murine genes in the HLH domain (Ellis et al. 1990) and has been shown recently to inhibit Drosophila basic $\mathrm{HLH}$ (bHLH) proteins from binding DNA in vitro (Van Doren et al. 1991). Some preliminary rules governing the association of Id and other bHLH proteins have been reported. For example, the affinity of murine Id 1 and Id2 for the E proteins is higher than their affinity for MyoD (Benezra et al. 1990; Sun et al. 1991). Furthermore, TFE3, a bHLH protein that also contains a leucine zipper (bHLH-zip), is completely resistant to Idl (Sun et al. 1991; Wilson et al. 1991) and Id2 inhibition, although the zipper is not necessary for this resistance (Sun et al. 1991). A similar resistance to Id inhibition has been reported for the bHLHzip proteins c-Myc, USF, and AP4 (Sun et al. 1991).

Thus far, the in vivo inhibitory activity of Id has been inferred from changes in Id mRNA expression and transient transfection data. Idl steady-state mRNA levels have been shown to be down-regulated during muscle 
differentiation (Benezra et al. 1990), and both mRNAs are down-regulated during B-cell development (Sun et al. 1991; Wilson et al. 1991), erythroid differentiation, and F9 embryonal carcinoma cell differentiation (Benezra et al. 1990; Sun et al. 1991). In addition, both Id 1 and Id3 are down-regulated in serum-deprived fibroblasts (Benezra et al. 1990; Christy et al. 1991), and Id3 has been shown to be a member of the early serum response genes (Christy et al. 1991). Transient transfection data are available only for Id 1 . In several different cell lines, Idl expression from a viral long terminal repeat (LTR) has been shown to antagonize the ability of positively acting bHLH proteins to activate transcription (Benezra et al. 1990; Cordle et al. 1991; Pongubala and Atchison 1991). Furthermore, when an E protein is forced to bind DNA by fusing it to the Gal4 DNA-binding domain, trans-activation of an upstream activating sequence (UAS) containing reporter gene by this molecule is insensitive to Id expression (Wilson et al. 1991). These data support a model in which Id inhibits differentiation by preventing $\mathrm{E}$ proteins alone or as heterodimeric complexes from binding DNA and trans-activating target genes.

Evidence for the interaction of various HLH proteins in vivo has come from genetic analysis and cell culture experiments. For example, in Drosophila, the negative HLH proteins emc and hairy appear to titrate the effects of two other HLH proteins involved in neuroblast determination, scute and achaete, respectively (Moscoso del Prado and Garcia-Bellido 1984; Alonso and Garcia-Bellido 1986; Ellis et al. 1990; Garrell and Modolell 1990). scute and daughterless (a Drosophila homolog of the E proteins) interact genetically during peripheral neurogenesis (Caudy et al. 1988; Dambly-Chaudiere et al. 1988). Also, daughterless and ectopically expressed hairy have been shown to compete genetically for limiting amounts of scute (Parkhurst et al. 1991). In cell culture transfection experiments, it has been observed that all mutations in $\mathrm{MyoD}$ that prevent its asociation with $\mathrm{E}$ proteins in vitro also inhibit its ability to trans-activate muscle-specific genes, suggesting the cooperation of these two HLH proteins in the cell (Davis et al. 1990). Furthermore, C3H10T1/2 cells, which underexpress E proteins as a result of antisense E12 expression, are resistant to conversion to muscle by MyoD overexpression (Lassar et al. 1991). One cannot rule out the possibility, however, that these effects are the result of indirect interactions.

Direct biochemical measurements of bHLH protein interactions have been reported recently, that is, E proteins complexed to MyoD and myogenin have been observed in muscle cell extracts (Lassar et al. 1991). We wanted to determine whether direct protein-protein interactions between Id and the E proteins play a role in muscle diffferentiation. In this report we demonstrate that Id and E proteins cofractionate and coimmunoprecipitate in extracts from proliferating myoblasts. We also correlate the loss of Id protein in differentiated myotubes with the appearance of hetero-oligomeric complexes between $\mathrm{E}$ proteins and MyoD in whole-cell extracts. These complexes do not form when purified Id protein is added back to the lysates. In addition, we show that stable overexpression of Id mRNA delays the onset of differentiation in the $\mathrm{C} 2 \mathrm{C} 12$ muscle cell line. Myotubes that do eventually form in these cells continue to express Id mRNA but have lost Id protein as assayed by indirect immunofluorescence and immunoprecipitation with an anti-Id antibody, implying post-transcriptional regulation of Id protein levels. Our data favor a model in which Id inhibits muscle differentiation in cultured cells by preventing the association of the $\mathrm{E}$ proteins with the muscle determination gene products.

\section{Results}

Id and E proteins coimmunoprecipitate from $P 2$ myoblasts

Id and E proteins, synthesized in reticulocyte lysates, form hetero-oligomeric complexes (Benezra et al. 1990). We sought to determine whether an E-Id complex existed in myoblast cell extracts. The strategy for this experiment is diagramed in Figure 1A. Nuclear extracts from disrupted myoblasts labeled with $\left[{ }^{35} \mathrm{~S}\right]$ methionine were first immunoprecipitated with an anti-E12 antibody in a low-stringency step (Fig. 1B, lane 2). As a consequence of the low-stringency conditions, many bands are present in this lane; however, one species specifically immunoprecipitated with this antiserum (and not preimmune serum from the same rabbit) is apparent and is indicated with an asterisk. This species has an apparent molecular mass of $\sim 70 \mathrm{kD}$, consistent with the predicted size of the E2A gene products. To determine whether Id coimmunoprecipitated with the E-protein immune complex, the pellet from the low-stringency step was treated briefly with a buffer containing SDS and sodium deoxycholate (see Materials and methods). These conditions disrupt HLH complexes in vitro (R. Benezra, unpubl.). An antibody specific for Id was then employed in a second immunoprecipitation reaction (high-stringency step). The immunoprecipitations needed to be performed in this order because our anti-Id antiserum disrupts HLH interactions in vitro (R. Benezra, unpubl.).

As shown in Figure 1B, when the anti-E12 antisera and anti-Id antisera were used in the low- and high-stringency steps, respectively, a protein doublet of 14 and 18 $\mathrm{kD}$ was observed (lane 5). These are the sizes observed for Id both in vivo (see below) and in reticulocyte lysate translations of the Id cDNA (Benezra et al. 1990), although the ratio of the intensity of these bands varied from experiment to experiment. When preimmune sera for E12 or Id are used in either the low- or high-stringency steps, respectively, this doublet is not observed (cf. lanes 3 and 4 with lane 5). On the basis of integrated intensities of the E2A bands in lane 2 and the Id bands in lane 5, we estimate that the molar ratio of Id/E2A in the complex is $1.2: 1$, after correcting for methionine content and exposure times (see Materials and methods). We suspect, therefore, that most, if not all, of the E proteins in the extract are associated with Id. This result seems reasonable, given the fact that we estimate about a $7: 1$ 
Jen et al.

$\underline{\mathrm{A}}$

1. Label cells with ${ }^{35} \mathrm{~S}$ - methionine and lyse under mild conditions

2. Immunoprecipitate with anti-E12 antibody and protein-A agarose beads ("LOW STRINGENCY RIP")

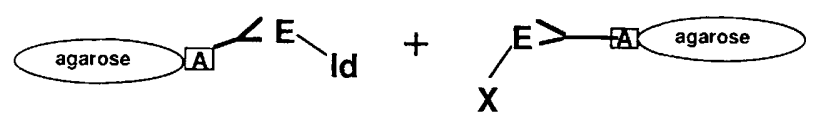

3. Break HLH complexes by treating beads with RIPA buffer
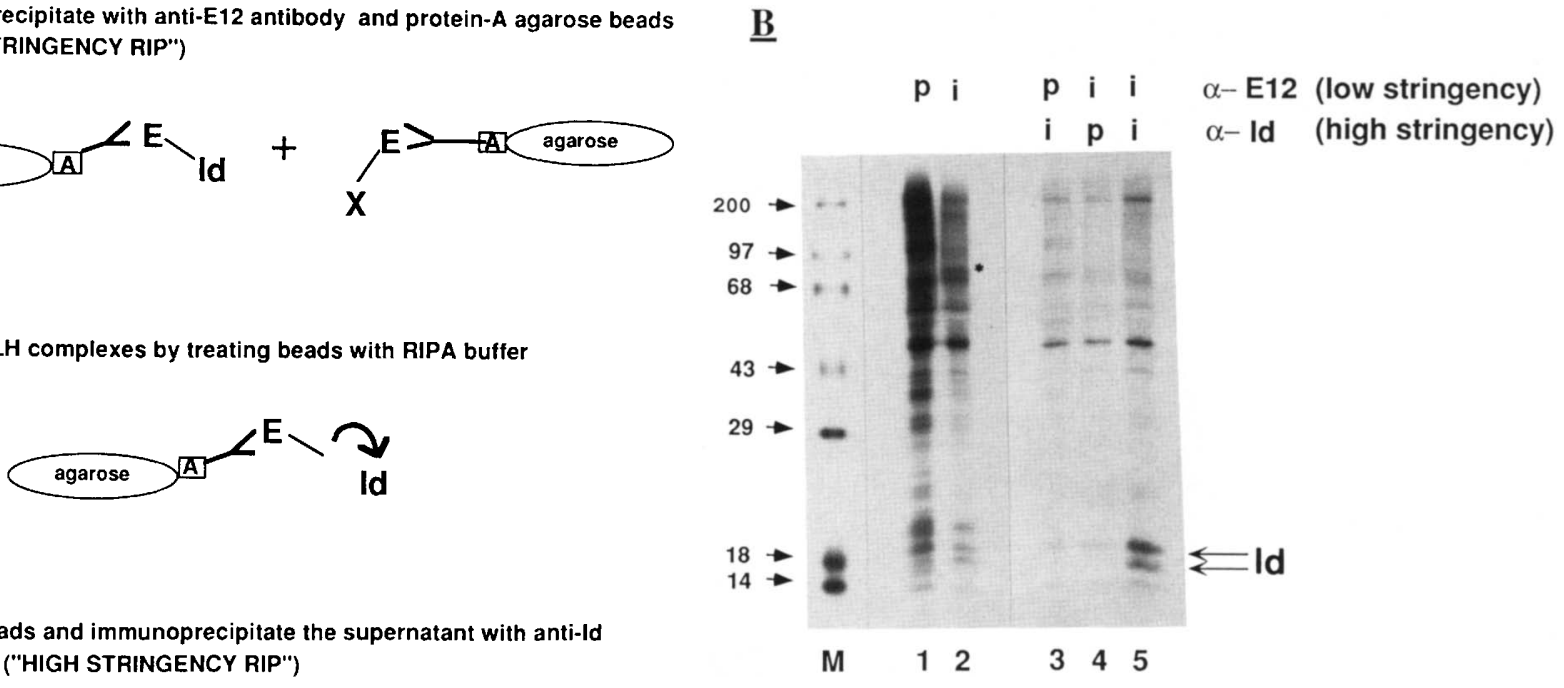

4. Pellet beads and immunoprecipitate the supernatant with anti-ld antibody ("HIGH STRINGENCY RIP")

Figure 1. Id coimmunoprecipitates with E2A proteins in a P2 myoblast cell lysate. $(A)$ Outline of the immunoprecipitation protocol used for detecting E-Id complexes in myoblast lysates. $(B)\left[{ }^{35} S \mid\right.$ Methionine-labeled P2 myoblasts were disrupted, as described in Materials and methods, and immunoprecipitated with preimmune serum (p) or anti-E12 antiserum (i) in a low stringency step (lanes 1 and 2, respectively). Parallel immunoprecipitates were then treated with RIPA buffer and reprecipitated under high-stringency conditions with preimmune (p) or an anti-Id antiserum (i) . (M) Molecular mass standards, with sizes indicated in kD. The arrows denote the positions of protein bands with the same apparent molecular mass as Id. The asterisk $(*)$ denotes the position of a protein species specifically immunoprecipitated with the anti-E12 antiserum.

molar ratio of total Id/total E released in the extract (not shown) and that a $2: 1 \mathrm{Id} / \mathrm{E} 47$ ratio in vitro yielded a quantitative association of E47 with Id (Benezra et al. 1990).

By use of the coimmunoprecipitation assay devised here, it has been reported recently that $\sim 5 \%$ of the $\mathrm{MyoD}$ in a proliferating myoblast is associated with $\mathrm{E}$ proteins (Lassar et al. 1991). This suggests that, at most, a small percentage of the available $\mathrm{E}$ protein in a proliferating myoblast is present in these complexes, as MyoD and $E$ proteins are present in roughly equal molar amounts (data not shown). This is consistent with our contention that most, if not all, of the E protein is complexed to Id in these cells. We do not know whether the small percentage of E protein associated with MyoD represents complexes present in an undifferentiated cell, complexes present in a subpopulation of cells that are beginning to differentiate, or simply an artifact of the handling of cell lysates.

Although it is formally possible that the coimmunoprecipitation result simply reflects cross-reactivity of the anti-E 12 antisera with Id in the low-stringency step, this is unlikely because no such cross-reactivity is observed in vitro under similar conditions (Benezra et al. 1990). In addition, such an interpretation would require that an antigen-antibody complex (between anti-E12 antibodies and Id) be disrupted by RIPA buffer, which is uncom- mon. We conclude from this experiment that Id and E proteins are associated in proliferating myoblast cells.

\section{Id and E proteins cofractionate in myoblast extracts}

If $\mathrm{E}$ proteins are associated with Id in proliferating myoblasts and unassociated with DNA, they might be expected to elute from disrupted myoblasts in low-ionicstrength buffers. To test this, the following fractionation protocol was employed. P2 myoblasts at $\sim 40 \%$ confluence were metabolically labeled with $\left[{ }^{35}\right]$ methionine and lysed in a homogenization buffer containing $0.5 \%$ NP- 40 and $10 \mathrm{~mm} \mathrm{NaCl}$, and the resulting nuclei were pelleted (see Material and methods). This $10 \mathrm{~mm} \mathrm{NaCl}$ lysate was decanted, and the nuclei were then extracted sequentially with 300 and $500 \mathrm{~mm} \mathrm{NaCl}$ for $2 \mathrm{~min}$ on ice.

Equal portions of the four resulting fractions $110 \mathrm{~mm}$ cytoplasmic, 300 and $500 \mathrm{~mm}$ nuclear, and the solubilized pellet) were then immunoprecipitated with polyclonal antibodies to E2A under the high-stringency conditions described in the previous section. The results are shown in Figure 2A. The most prominent species immunoprecipitated with this antiserum migrate with apparent molecular masses of $\sim 70 \mathrm{kD}$, consistent with the predicted sizes of known E proteins and the sizes of protein species that are lost in cell lines expressing antisense E12 mRNA (Lassar et al. 1991). In proliferating 
A

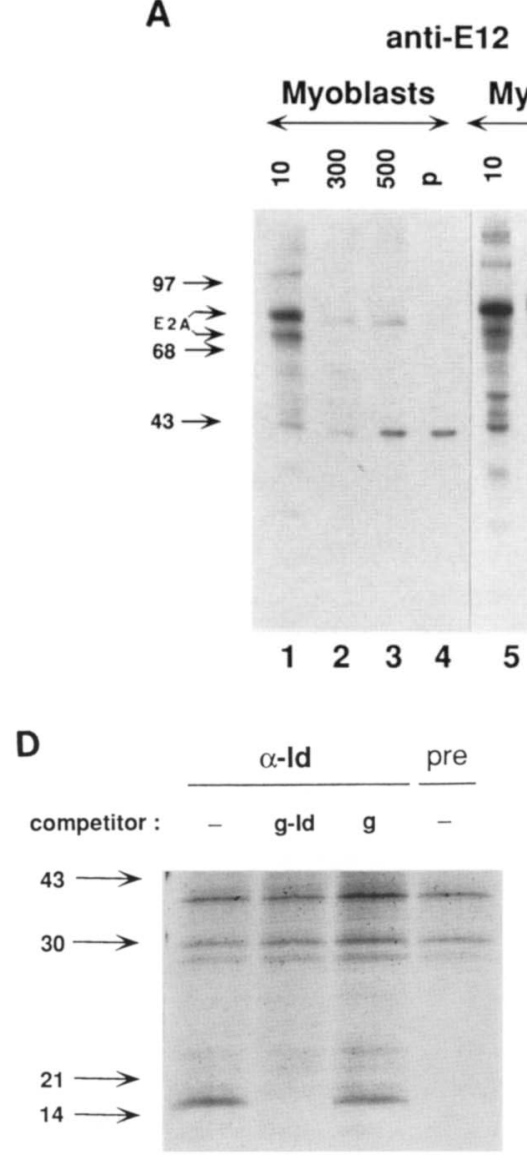

\section{B}

$$
\begin{aligned}
& \alpha \text {-ld } \\
& \text { Myoblasts } \\
& \stackrel{\longleftrightarrow}{\stackrel{\circ}{\circ} \mathrm{o}}
\end{aligned}
$$

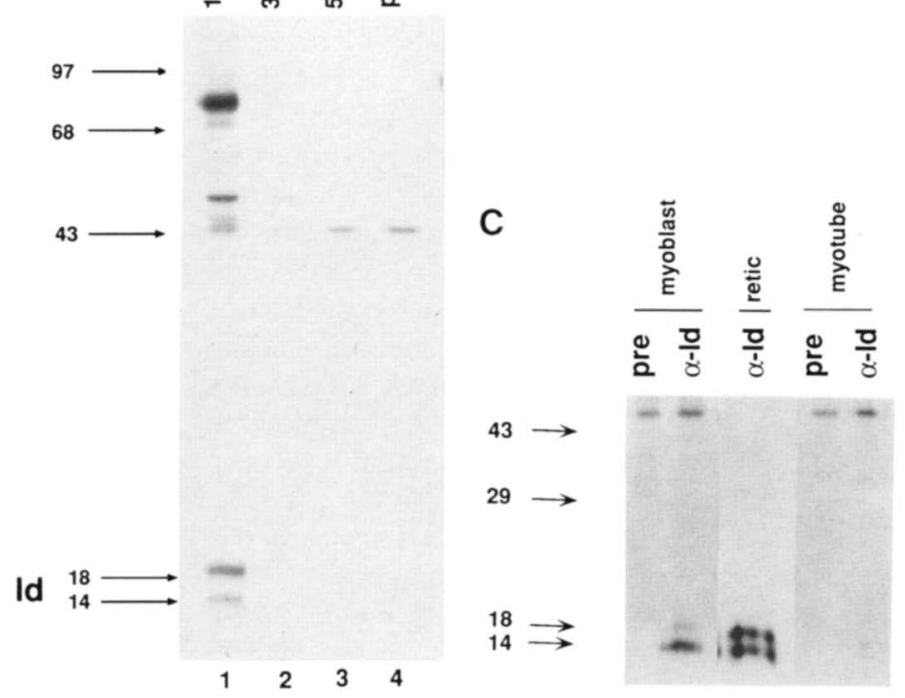

Figure 2. Salt fractionation of $\mathrm{E} 2 \mathrm{~A}$ and $\mathrm{MyoD}$ proteins in $\mathrm{P} 2$ myoblasts and myotubes. $|A|$ Proliferating P2 myoblasts and differentiated myotubes were metabolically labeled with ${ }^{35}$ S|methionine. After disruption of the cell membranes in buffer containing $10 \mathrm{~mm} \mathrm{NaCl}$ and $0.5 \%$ NP- 40 , the nuclei were pelleted, the $10 \mathrm{~mm} \mathrm{NaCl}$ cytoplasmic fraction was withdrawn, and the nuclei were extracted sequentially with buffers containing 300 and $500 \mathrm{~mm}$ $\mathrm{NaCl}$. These fractions, along with the sonicated residual nuclear pellets, were immunoprecipitated with an anti-E12 antiserum, and the precipitates were electrophoresed on a $15 \%$ discontinuous SDS-polyacrylamide gel. The gel was fixed, dried, and autoradiographed for 5 days. The arrows between the 68 - and $97-\mathrm{kD}$ markers indicate the positions of the $\mathrm{E}$ proteins. $(B)$ Myoblast extracts prepared in parallel to those in $A$ were immunoprecipitated with an anti-Id antiserum and analyzed as described above. Id protein migrates with the 14- and 18-kD protein standards as shown in $C$ and $D .(C)$ P2 myoblasts and myotubes metabolically labeled with $\left[{ }^{35} S\right]$ methionine and reticulocyte lysates incubated with synthetic Id mRNA and ${ }^{35} S \mid$ methionine were immunoprecipitated with preimmune or anti-Id antiserum. The precipitates were analyzed as in $A$. (D) Labeled P2 myoblast lysates were immunoprecipitated as in $C$ (lane 1$)$ or the anti-Id antiserum was first competed with either purified GEX-Id (lane 2) or GEX (lane 3), as described in Materials and methods.

myoblasts, these E protein species were eluted primarily in the $10 \mathrm{~mm}$ fraction $(86.4 \%$ by densitometric analysis; lane 1), with the residual material distributed in the 300 $\mathrm{mm}$ (lane 2) and $500 \mathrm{~mm}$ (lane 3$)$ fractions $(5.4 \%$ and $8.2 \%$, respectively).

Id was extracted from proliferating myoblasts quantitatively in the $10 \mathrm{~mm}$ fraction (Fig. 2B). That the two bands indicated are Id is demonstrated in Figure 2, C and D. These bands comigrate with Id immunoprecipitated from reticulocyte lysates, decrease $\sim 10$-fold in differentiated myotubes, and are not observed when a preimmune antiserum is employed (Fig. 2C). In addition, preincubation of the antiserum with a purified glutathione S-transferase-Id fusion protein (referred to as GEX-Id) specifically blocks the appearance of these bands in the immunoprecipitate, whereas the glutathione S-transferase leader alone (GEX) has no effect (Fig. 2D). Because Id (see below) and the E proteins (data not shown) are nuclear localized by immunofluorescence, we conclude that the majority of both proteins is coming out of the nucleus under low-ionic-strength conditions. This behavior is consistent with the idea that both proteins are in the nucleoplasm unassociated with DNA. We cannot determine whether the residual $\mathrm{E}$ protein eluted in the 300 and $500 \mathrm{~mm}$ fractions represents material that has escaped Id inhibition in undifferentiated myoblasts or whether it is contributed by spontaneously differentiating cells in our proliferating cultures (see below).

A similar assay was performed with P2 cells that had been placed under differentiation conditions for $48 \mathrm{hr}$ before labeling. Approximately $50 \%$ of the cells in this experiment had fused into multinucleate syncytia, characteristic of mature myotubes. As stated above, Id protein levels decrease significantly under these conditions and, in a typical experiment, were observed to decrease 10.7-fold (Fig. 2C). As shown in Figure 2A, the E proteins extracted from these cells are present in roughly equal proportions in the 10 and $300 \mathrm{~mm} \mathrm{NaCl}$ fractions $158 \%$ and $42 \%$, respectively, as measured densitometrically; lanes 5,6$)$. The E proteins eluted in the $300 \mathrm{~mm}$ fraction 
consistently migrated more slowly than those eluted in the $10 \mathrm{~mm}$ fraction. These slower migrating species are also not present in the $10 \mathrm{~mm} \mathrm{NaCl}$ extracts from myoblasts (cf. lanes 1 and 6). The $\mathrm{E}$ proteins present in the $300 \mathrm{~mm}$ myotube fraction are not simply spillover from the $10 \mathrm{~mm}$ fraction because a second $10 \mathrm{~mm}$ extraction did not yield a significant amount of immunoprecipitable E protein (data not shown). Finally, we note that the E proteins eluted at $10 \mathrm{~mm} \mathrm{NaCl}$ from the myotube cultures may represent material preferentially contributed by undifferentiated myoblasts in the population, $\sim 30$ $50 \%$ of the cells in a typical experiment.

Thus, the loss of Id protein in myotubes is associated with a shift in the salt elution profile and the electrophoretic properties of the E proteins. Given previous in vitro (Murre et al. 1989a; Benezra et al. 1990) and in vivo (Wilson et al. 1991) results, it seems reasonable to suppose that the $\mathrm{E}$ proteins in the $300 \mathrm{~mm}$ fraction are associated with DNA. We are currently trying to determine whether the altered mobility of the protein in this fraction is the result of post-translational modification, alternate RNA splicing, or the induction of a new E protein-related gene.

The absence of Id correlates with the presence of high-affinity E/MyoD DNA-binding complexes in whole-cell extracts of myotubes

We have proposed that in proliferating myoblasts, Id prevents the association of $\mathrm{E}$ proteins with muscle regula- tory genes such as MyoD or myogenin by direct competition. Upon serum withdrawal, when Id protein levels fall, we imagine that $E$ proteins become free to associate with the muscle regulatory proteins and that these hetero-oligomeric complexes now bind with high affinity to response elements in muscle-specific structural genes. If this model is correct, one would expect to find an increase in muscle creatine kinase (MCK) enhancer-binding activity in extracts prepared from differentiated myotubes relative to that of proliferating myoblasts.

Whole-cell extracts were prepared from C3H10T1/2 fibroblasts, proliferating P2 myoblasts, and differentiated myotubes, as described in Materials and methods. (Note that it was necessary to prepare whole-cell extracts as opposed to nuclear extracts because E proteins and Id are extracted in the cytoplasmic fractions of P2 cells, as shown in the previous section.) Extracts were then incubated with a radiolabeled oligonucleotide from the $\mathrm{MCK}$ enhancer plus increasing amounts of poly[d(I-C)], and the complexes were resolved from the free probe on a nondenaturing polyacrylamide gel. The results are shown in Figure 3. Little difference is observed in the complexes formed in C3H10T1/2 extracts compared with those of P2 myoblasts (cf. lanes 1-3 with 4-6). A prominent band that does not contain MyoD or E2A (see below) is observed in both cell types. Extracts from differentiated P2 myotubes, on the other hand, show new, slower migrating shifted species (lanes 7-9), and the prominent nonMyoD/E2A complex is lost despite the presence of excess probe.

A

Whole Cell Extracts + MCK Enhancer

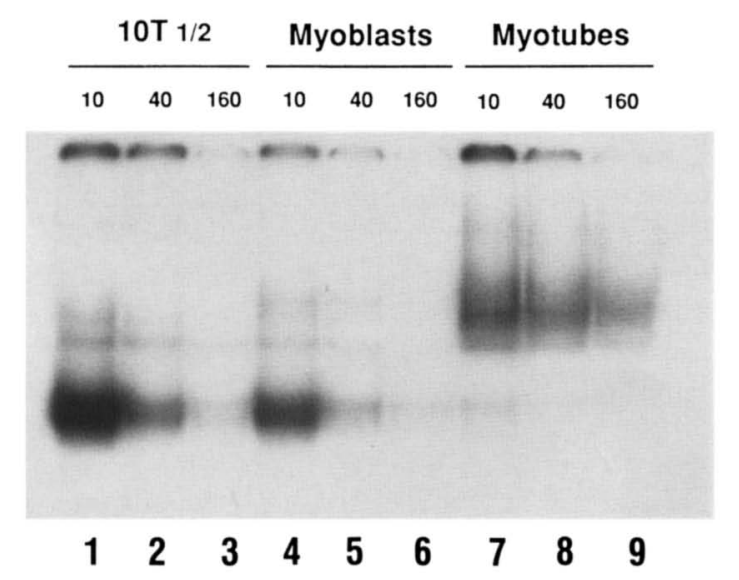

B

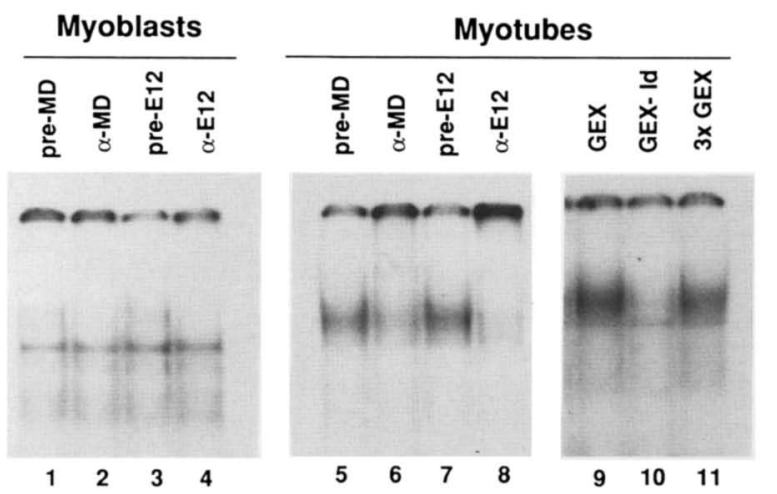

Figure 3. Whole cell extracts from myotubes, but not myoblasts, contain complexes that bind with high affinity to the MyoD consensus sequence. $(A)$ EMSA was performed with whole-cell extracts from the indicated cell types and a radiolabeled oligonucleotide containing the MyoD consensus-binding site as described in Materials and methods. The samples were electrophoresed on a 5\% nondenaturing acrylamide gel. Double-stranded poly[d(I-C) $](10,40$, and $160 \mathrm{ng})$ was used as nonspecific competitor, as indicated. Note that the free oligonucleotide probe runs below the region of the gel displayed. $(B)$ Whole-cell extracts from myoblasts and myotubes were tested as in A ( $+40 \mathrm{ng}$ of poly [d(I-C)]), but the complexes were first preincubated with IgG fractions isolated from preimmune MyoD antiserum (lanes 1,5), an anti-MyoD antiserum (lanes 2,6), preimmune E12 antiserum (lanes 3,7), or anti-E12 antiserum (lanes 4,8 ). In lanes 9-11, extracts were preincubated with $10 \mathrm{ng}$ of purified GEX or GEX-Id (lanes 9,10) or 30 ng of GEX (lane 11) before the addition of the oligonucleotide probe. 
To demonstrate that the myotube-specific proteinDNA complexes contain E proteins, the protein-DNA complexes were incubated with preimmune and immune anti-E12 IgG. As shown in Figure 3B, our anti-E12 IgG preparation specifically eliminates most of the myotube-specific species relative to the preimmune control (cf. lanes 7 and 8). No effect is observed with the anti-E12 IgG on the protein-DNA complexes in myoblasts (lanes 3,4 ) and C3H10T1/2 cells (data not shown). Similarly, an anti-MyoD IgG preparation partially inhibits the myotube-specific shift relative to a preimmune control (cf. lanes 5 and 6) with little effect on the complexes present in myoblasts (lanes 1,2$)$. These data suggest that the myotube-specific protein-DNA complexes that we observe contain E proteins and that a subpopulation of the complexes also contain MyoD. It is likely that the residual material present in lane 6 is a myogenin/E-protein complex based on previously published data (Lassar et al. 1991). Finally, we show that the myotube-specific protein-DNA complexes are disrupted by prior incubation with purified GEX-Id protein but not with GEX alone (lanes 9-11). In addition, the species running just ahead of the myotube-specific complexes that is also present in myoblasts is relatively unaffected by the addition of purified Id (lanes 9,10). Thus, the loss of Id protein observed during myotube formation correlates with the appearance of $\mathrm{E}$ protein-containing $\mathrm{MCK}$ enhancer-binding activity, which is inhibited by the addition of purified Id. These data provide additional experimental support for the competitive model described above.

\section{Overexpression of Id delays the onset of differentiation in C2C12 myoblasts}

We have tested directly the ability of Id to inhibit differentiation of myoblasts by stable overexpression of an Id cDNA in the $\mathrm{C} 2 \mathrm{C} 12$ cell line. $\mathrm{C} 2 \mathrm{C} 12$ cells were coelectroporated with a plasmid carrying the neomycin resistance gene and either a plasmid with Moloney sarcoma virus (MSV) LTR alone (EMSV) or the MSV LTR upstream of the entire Id cDNA [E : Id(S)]. The electroporated cells were selected in G418 for 2 weeks, at which time individual colonies were observed. We first noted that the frequency of G418-resistant colonies was markedly reduced in the cells transfected with $\mathrm{E}: \operatorname{Id}(\mathrm{S})$ relative to EMSV alone, suggesting some type of growth inhibition as a result of high-level Id expression /data not shown). A similar growth inhibitory effect has been observed in cells overexpressing MyoD (Crescenzi et al. 1990; Sorrentino et al. 1990), and emc has been shown to affect cell proliferation in Drosophila embryos (Alonso and Garcia-Bellido 1988).

To determine whether Id overexpression had any effect on the differentiation potential of $\mathrm{C} 2 \mathrm{C} 12$ cells, we compared the behavior of polyclones of $\mathrm{C} 2 \mathrm{C} 12$ cells transfected with $\mathrm{E}: \mathrm{Id}(\mathrm{S})$ to control lines transfected with EMSV alone. The $\mathrm{E}: \operatorname{Id}(\mathrm{S})$ and the EMSV polyclones were comprised of 4 and 20 independent clones, respectively. Cultures were harvested while proliferating or 16 and $40 \mathrm{hr}$ after serum withdrawal, and cytoplasmic RNA was prepared as described (see Materials and methods). We first noticed that the EMSV polyclone, but not the $\mathrm{C} 2 \mathrm{E}: \mathrm{Id}(\mathrm{S})$ polyclone, showed prominent myotube formation after $16 \mathrm{hr}$ of mitogen deprivation (data not shown). By $40 \mathrm{hr}$ after serum deprivation, the $\mathrm{C} 2 \mathrm{E}: \mathrm{Id}(\mathrm{S})$ polyclone appeared to contain some mature myotubes, but most of the cells appeared inviable, and it was not possible to prepare intact RNA (data not shown).

A Northern analysis of the recovered RNA samples is shown in Figure 4. Hybridization to the Id cDNA probe shows that the C2E : Id(S) polyclone expresses 3.1- and 15.5-fold more Id mRNA than the C2EMSV polyclone in the proliferating state and $16 \mathrm{hr}$ after serum withdrawal, respectively (all numbers are normalized to the $18 \mathrm{~S}$ and 28S rRNA bands shown). Rehybridization of the filter to a myosin light-chain (MLC) cDNA probe demonstrated that while the C2EMSV polyclone was expressing near maximal amounts of MLC mRNA after $16 \mathrm{hr}$ of serum deprivation (48\%, cf. $16-$ and 40 -hr time points), very little MLC mRNA was expressed in the C2E : Id(S) polyclone after $16 \mathrm{hr}$ in serum-free media. Densitometric analysis indicates that the ratio of MLC mRNA in the

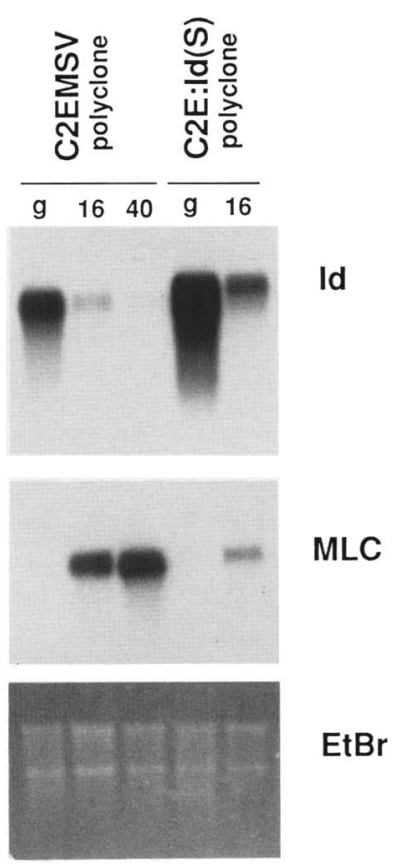

Figure 4. Overexpression of Id inhibits the differentiation of $\mathrm{C} 2 \mathrm{C} 12$ cells. Early-passage polyclones of $\mathrm{C} 2 \mathrm{C} 12$ cells stably transfected with the EMSV expression vehicle alone (C2EMSV) were harvested while growing (g) or 16 and $40 \mathrm{hr}$ after serum withdrawal, and cytoplasmic RNA was prepared. Early-passage polyclones of $\mathrm{C} 2 \mathrm{C} 12$ cells transfected with EMSV containing the Id cDNA [C2E : Id(S)] were processed similarly while growing $(g)$ or $16 \mathrm{hr}$ after serum withdrawal. A Northern blot prepared with $5 \mu \mathrm{g}$ of each RNA sample was probed first with the Id cDNA then with a MLC probe. (EtBr) The fluorescence pattern observed when $0.5 \mu \mathrm{g}$ of cytoplasmic RNA from the same sample preparations was electrophoresed on a $1.5 \%$ agarose gel and stained with ethidium bromide (EtBr). 
C2EMSV/C2E : Id(S) polyclones is $3.1: 1$ after $16 \mathrm{hr}$ of serum deprivation. Thus, both morphologically and by the criterion of MLC expression, deregulated expression of Id correlates with an inhibition of the differentiation program of $\mathrm{C} 2 \mathrm{C} 12$ cells after $16 \mathrm{hr}$ of mitogen withdrawal. The inviability of the $\mathrm{C} 2 \mathrm{E}: \mathrm{Id}(\mathrm{S})$ polyclone after $40 \mathrm{hr}$ in serum-free media is consistent with a growthsuppressive effect of Id overexpression as described above. Interestingly, polyclonal cultures of $\mathrm{E}: \mathrm{Id}(\mathrm{S})$ consistently failed to grow after three to four serial passages while the control C2EMSV cultures remained viable.

We sought to isolate a $\mathrm{C} 2 \mathrm{C} 12$ cell line overexpressing Id that could be maintained in continuous culture. Of $\sim 20$ clones screened, only 1 remained viable after multiple passages. This cell line [C2E : Id(S)] was analyzed along with the parental $\mathrm{C} 2 \mathrm{C} 12$ line $(\mathrm{C} 2)$, and a single clone was transfected with the EMSV vector (C2EMSV), as described above for the polyclonal cultures. We first noticed that both C2 and C2EMSV showed prominent fusion in densely packed colonies even when maintained in high serum, whereas $\mathrm{C} 2 \mathrm{E}: \mathrm{Id}(\mathrm{S})$ cells did not (data not shown|. Also, 12-16 hr after senum withdrawal, very little myotube formation was observed in monolayer cultures of C2E : Id(S) compared with the control cell lines. By $48 \mathrm{hr}$ after serum withdrawal, however, prominent fusion was observed in all three cell lines.

Northern analysis of cytoplasmic RNA prepared from $\mathrm{C} 2$, C2EMSV, and C2E : Id(S), while proliferating or 16 and $48 \mathrm{hr}$ after serum withdrawal, is presented in Figure 5. A marked reduction of Id mRNA after 16 and $48 \mathrm{hr}$ in serum-free media was observed in C2 and C2EMSV relative to that of proliferating populations. (C2EMSV cells show a 10.5- and 36.7-fold decrease after 16 and $40 \mathrm{hr}$, respectively. $\mathrm{C} 2 \mathrm{C} 12$ cells show a 15 - and 10-fold decrease, respectively. All numbers are normalized to $18 \mathrm{~S}$ and $28 \mathrm{~S}$ rRNA levels.) $\mathrm{C} 2 \mathrm{E}: \mathrm{Id}(\mathrm{S})$ cells, on the other hand, showed hybridization to a slighly slower mobility RNA species, derived from the transfected gene, which increased in concentration as the cells were induced to differentiate. A 2.0-fold increase was measured after 40 $\mathrm{hr}$ postserum withdrawal. This increase may be due to the fact that the MSV enhancer is activated under lowserum conditions by MyoD (R. Benezra, unpubl.).

MyoD mRNA levels are reduced in proliferating $\mathrm{C} 2 \mathrm{E}$ : Id cells relative to C2EMSV or $\mathrm{C} 2 \mathrm{C} 12$ cells $33.7-$ and 4.5-fold, respectively) and increase with induction in C2E : Id(S) cells (2.0- and 4.2-fold after 16 and $40 \mathrm{hr}$, respectively; see Fig. 5). This may reflect the requirement for HLH proteins to maintain MyoD expression in myoblasts and that these proteins are inhibited by deregulated expression of Id. This inhibition would be alleviated when Id protein levels fall during differentiation (see below). A similar result was observed in the Id-overexpressing polyclone (data not shown).

We then assayed these cell populations for expression of the MLC $1 / 3$ gene (Fig. 5, MLC panel) as an indicator of muscle differentiation. Consistent with the results shown in Figure 4, both C2EMSV and C2C12 cells expressed approximately one-half maximal levels of MLC mRNA after $16 \mathrm{hr}$ of induction $55 \%$ and $55 \%$, respec-

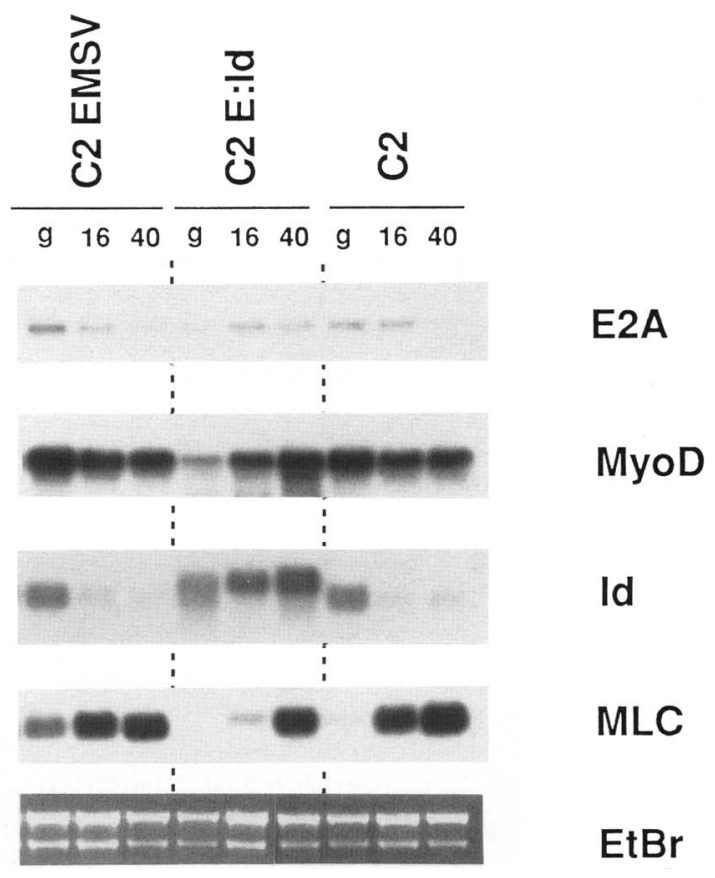

Figure 5. Five micrograms of cytoplasmic RNA from stably propagated, individual clones of $\mathrm{C} 2 \mathrm{C} 12$ cells (see text) was analyzed by Northern analysis as described in Materials and methods. C2E : Id refers to the C2E : Id(S) clone described in the text. The same filter was hybridized four separate times to the probes indicated. $\mathrm{EtBr}$ is as described in Fig. 4.

tively, of the levels observed after $40 \mathrm{hr}$ postserum withdrawal). C2E : Id(S), on the other hand, showed only $6.3 \%$ of the maximal MLC levels after $16 \mathrm{hr}$ of induction. In absolute terms, this corresponds to an $11: 1$ ratio of MLC mRNA in C2EMSV relative to C2E : Id(S) and $12: 1$ in $\mathrm{C} 2 \mathrm{C} 12$ relative to $\mathrm{C} 2 \mathrm{E}: \mathrm{Id}(\mathrm{S})$. After $48 \mathrm{hr}$, however, as much MLC mRNA was observed in C2E : Id(S) as in the control cultures. The pattern of MLC expression observed in these three cells lines is highly reproducible, as three independent Northern analyses performed during 3-4 months in continuous culture yielded identical results (data not shown).

To determine whether Id protein is present in differentiated $\mathrm{C} 2 \mathrm{E}: \operatorname{Id}(\mathrm{S})$ cells, we examined, by indirect immunofluorescence, Id and myosin heavy-chain (MHC) protein levels in $\mathrm{C} 2 \mathrm{E}: \mathrm{Id}(\mathrm{S})$ cells $\sim 20 \mathrm{hr}$ after serum withdrawal. The anti-Id antiserum employed in these studies was raised against a GEX-Id fusion protein and produced prominent nuclear staining in 10T1/2 (Fig. 6), P2 myoblasts (data not shown), and $\mathrm{C} 2 \mathrm{C} 12$ myoblasts (see below). As shown in Figure 6, this staining is competed with extracts from GEX-Id-expressing bacterial cells but not with cells expressing GEX alone. In addition, only diffuse cytoplasmic staining is observed with preimmune sera from this rabbit (data not shown). We believe, therefore, that the immunofluorescence observed with our antiserum is a measure of Id protein levels in the nucleus. 


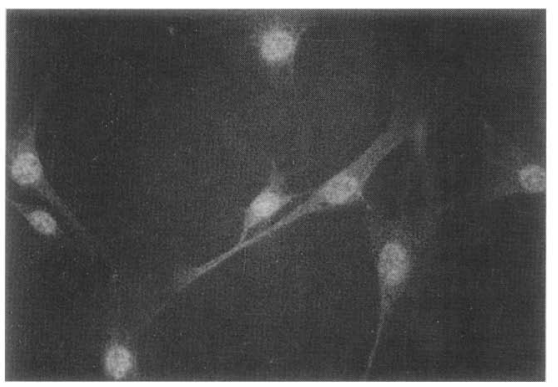

+ GEX

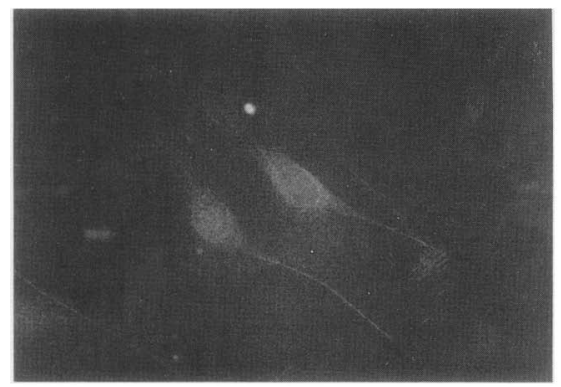

+ GEX-Id
Figure 6. Anti-Id antibody specifically stains the nucleus. C3H10T $1 / 2$ cells were stained with an anti-Id antibody preabsorbed with a lysate from bacteria expressing GEX alone (left) or a lysate from bacteria expressing a GEX-Id fusion protein (right) (see Materials and methods).
As shown, C2E : Id cells that are not expressing MHC protein (Fig. 7, left) show nuclear staining with the antiId antiserum (Fig. 7, right). C2E : Id cells expressing MHC in the cytoplasm, however, show a loss of Id nuclear staining (Fig. 7). The most convincing reduction in Id staining is observed in the nuclei of cells that are just beginning to expresss $\mathrm{MHC}$ in the cytoplasm (Fig. 7, center of the field). This is because cells expressing high levels of MHC often show a diffuse staining pattern over the entire cell with the anti-Id antiserum. We do not believe that this diffusely stained material is Id protein, however, because fully differentiated $\mathrm{C} 2 \mathrm{C} 12$ control cells that have extremely low levels of Id mRNA or Id protein (as assayed by immunoprecipitation; see below) show a similar pattern of staining (data not shown).

If the persistence of Id protein in C2E : Id(S) cells is responsible for the block in differentiation after $16 \mathrm{hr}$ of serum withdrawal, then an increase in immunoprecipitable Id protein should be observed in these cells relative to control C2EMSV cultures. Both cell types were metabolically labeled with $\left[{ }^{35} \mathrm{~S}\right]$ methionine for $16 \mathrm{hr}$ while proliferating or 16 and $40 \mathrm{hr}$ after serum withdrawal. Cell lysates were prepared and immunoprecipitated with a preimmune or anti-Id antiserum as described in Materials and methods. The results are shown in Figure 8A. One protein species with an apparent molecular mass of $\sim 18 \mathrm{kD}$ is specifically immunoprecipitated with the anti-Id antiserum from both proliferating cultures. This size corresponds to the slower migrating Id species observed in P2 myoblasts and reticulocyte lysates. This species is specifically competed with purified GEX-Id fusion protein but not GEX alone, as shown in Figure 8B (cf. lanes 2 and 3). (Note that in Fig. $8 \mathrm{~B}$ the lysates were precleared with preimmune antisera and protein $\mathrm{A}$-agarose beads at $4^{\circ} \mathrm{C}$ to reduce the intensity of the background bands observed in 8A.) At 16 and $40 \mathrm{hr}$ after serum withdrawal, the intensity of the Id band in the C2EMSV cell line decreases to $11 \%$ of that observed in the proliferating state. In the $\mathrm{C} 2 \mathrm{E}: \mathrm{Id}(\mathrm{S})$ culture however, the intensity of this band is $74 \%$ and $26 \%$ that observed in the proliferating state after 16 and $40 \mathrm{hr}$ of serum withdrawal, respectively. The ratio of the integrated intensity of the $18-\mathrm{kD}$ species after $16 \mathrm{hr}$ of serum withdrawal in C2E : Id(S)/C2EMSV is $4.5: 1$. Thus, an elevated level of Id protein after $16 \mathrm{hr}$ of serum withdrawal in the C2E : Id(S) cell line correlates with the fail-

\section{$\alpha \mathrm{MHC}$}

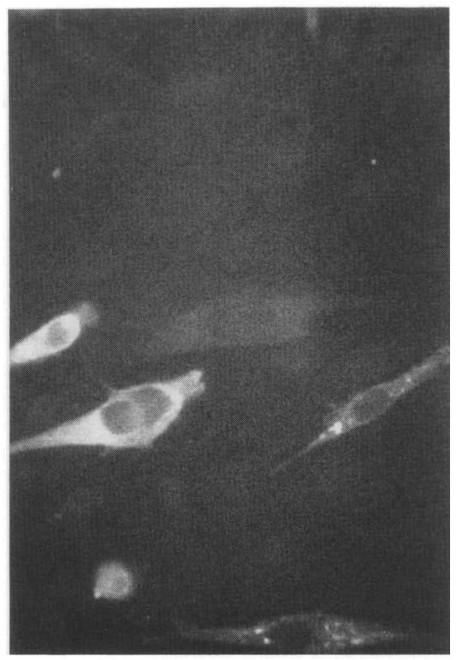

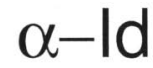

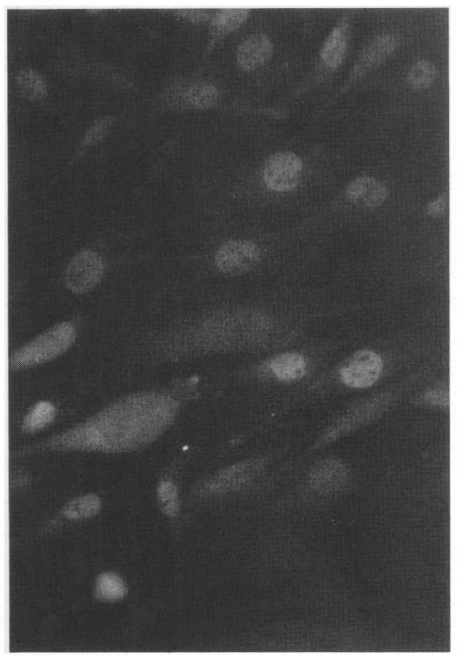

Figure 7. Differentiated C2E : Id cells show a loss of Id nuclear staining. $\mathrm{C} 2 \mathrm{E}$ : Id cells were grown in serum-free media for $20 \mathrm{hr}$ and then stained with antibodies to MHC and Id, as described in Materials and methods. 
Jen et al.

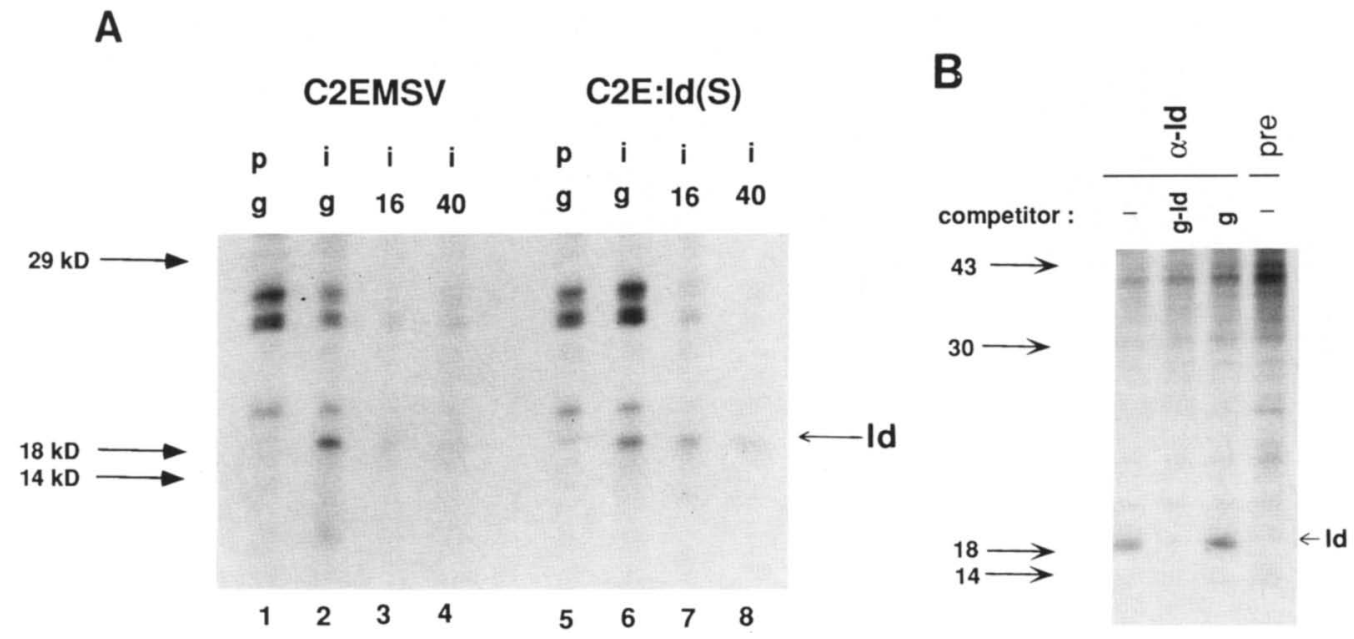

Figure 8. Id protein persists in C2E : Id(S) cells $16 \mathrm{hr}$ after serum withdrawal. $(A) \mathrm{C} 2 \mathrm{EMSV}$ and C2E : Id(S) cells growing $(g)$ or serum starved for 16 and $40 \mathrm{hr}$ were metabolically labeled with $\left.{ }^{35} \mathrm{~S}\right]$ methionine for $20 \mathrm{hr}$ and then immunoprecipitated with a preimmune (p) or anti-Id antiserum (i), as indicated. The positions of 14 - and $18-\mathrm{kD}$ molecular mass standards are indicated. (B) Lysates from $\mathrm{C} 2 \mathrm{C} 12$ cells labeled with $\left[{ }^{35}\right.$ S|methionine were precleared with preimmune serum and then immunoprecipitated with untreated anti-Id antiserum (lane 1), anti-Id antiserum competed with GEX-Id (lane 2) or GEX alone (lane 3), or untreated preimmune antiserum (lane 4).

ure of these cells to differentiate. There is a further 2.8 fold decrease in Id protein in C2E : Id(S) cells after $40 \mathrm{hr}$ in serum-depleted media; and as shown in Figure 7, residual Id is confined to the nucleus of nondifferentiated cells in the culture. Note also that the pattern of Id protein expression in $\mathrm{C} 2 \mathrm{E}: \operatorname{Id}(\mathrm{S})$ is dramatically different than the pattern of mRNA expression in this time course, supporting the idea that there is post-transcriptional control of Id protein in these cells.

We have consistently observed that Id protein immunoprecipitated from $\mathrm{C} 2 \mathrm{C} 12$ cells runs as the slower migrating species of the doublet immunoprecipitated from P2 aza-myoblasts. On longer exposure of the autoradiograph shown in Figure 8, the 14-kD Id band (or faster migrating species) is visible and behaves similarly to the $18-\mathrm{kD}$ band displayed (data not shown). We do not know the nature of the difference between these two species, although the faster migrating species comigrates with the primary translation product produced in reticulocyte lysates (Benezra et al. 1990).

\section{Discussion}

Negative regulation of HLH DNA-binding proteins may be mediated, in part, by direct protein-protein interactions. Id, an HLH protein lacking the DNA-binding domain, can associate in vitro with the ubiquitously expressed HLH protein products of the E2A gene (see introductory section) and prevent their binding to DNA either as homo-oligomers or hetero-oligomers with the muscle-specific transcription factor MyoD (Benezra et al. 1990). A related mechanism has been postulated for the negative regulator emc, a Drosophila HLH protein homologous to Id (Ellis et al. 1990; Garrell and Modolell 1990; Van Doren et al. 1991). Thus, by regulating the association of various HLH proteins, the cell may be able to coordinate the timing of transcriptional activation events during development. This type of biological control mechanism appears to be widely used since a homeo domain protein (I-POU) and a leucine zipper protein (CHOP-10) with disrupted DNA-binding domains appear to act as dominant-negative regulators of these families by direct protein-protein interactions (Treacy et al. 1991; Ron and Habener 1992).

We tested whether Id and E proteins synthesized in a myoblast could form a hetero-oligomeric complex by a two-step coimmunoprecipitation procedure. After immunoprecipitating a P2 myoblast extract with an antiE12 antibody, the precipitate was treated with a buffer (RIPA) that disrupts HLH interactions. The released material was shown to contain two protein species that reacted with an anti-Id antibody. These proteins run with the same apparent molecular mass as in vitro-translated Id protein and Id protein immunoprecipitated from labeled myoblasts. This experiment therefore provides direct biochemical evidence that the HLH proteins, Id and $\mathrm{E}$, synthesized in a myoblast are capable of forming a hetero-oligomeric complex. Furthermore, from an estimate of the amount of Id coimmunoprecipitated with E2A proteins, we believe that nearly all of the E2A protein detected with the antisera is complexed to Id.

To further investigate whether E proteins and Id can associate in the cell, we fractionated cellular lysates from myoblasts and myotubes by sequentially extracting nuclei with increasing ionic strength buffers and then immunoprecipitating with the appropriate antisera. To our surprise, both Id and E proteins, which localize to the nucleus by indirect immunofluorescence, were released nearly quantitatively in the cytoplasmic fraction of proliferating myoblasts. This behavior is characteristic of 
proteins that are free in the nucleoplasm, unassociated or weakly associated with DNA. In extracts from mature myotubes, in which total Id protein levels were $\sim 10$-fold lower than in myoblasts, the extraction pattern of the $\mathrm{E}$ proteins showed a marked difference from that of proliferating myoblasts. Roughly $50 \%$ of the immunoprecipitable $\mathrm{E}$ protein appears in the nuclear fraction of myotube lysates. Interestingly, this nuclear material migrated with slighly slower mobility in SDS-acrylamide gels. We are currently trying to determine whether these species are modified forms of the E proteins, alternate splice products of the E2A gene, or new members of the E-protein family.

If Id is inhibiting the formation of a MyoD-E complex in myoblasts, one would expect to find an increase in high-affinity MCK enhancer-binding activity in wholecell extracts from myotubes, in which Id protein is lost, relative to myoblasts. Myotube-specific E-box-binding complexes have been observed by others (Buskin and Hauschka (1989) and shown to contain myogenin and MyoD (Brennan and Olson 1991; Rosenthal 1992). We have also observed the formation of myotube-specific E-box-binding complexes in whole-cell extracts and have shown that these complexes contain $\mathrm{E}$ proteins as assayed by double-shift experiments. MyoD is also present in the complexes by this criterion. Importantly, these complexes do not form when purified Id is added to the extracts. Therefore, Id is sufficient to prevent the formation of MyoD-E protein complexes from forming on the MCK enhancer. In addition, we have observed that an E-box-binding complex not containing either E2A protein or MyoD is present at higher levels in whole-cell extracts from $10 \mathrm{~T} 1 / 2$ cells and undifferentiated myoblasts relative to myotubes, suggesting the possibility that the enhancer is occupied by Id-resistant DNA-binding proteins in cells not expressing MCK transcripts.

Finally, we tested whether constitutive expression of Id in a myoblast can block the onset of differentiation in response to serum deprivation. We first observed that polyclones of $\mathrm{C} 2 \mathrm{C} 12$ cells overexpressing Id failed to differentiate after $16 \mathrm{hr}$ of serum deprivation, whereas control cells were fully differentiated at this time. After 48 $\mathrm{hr}$ in mitogen-depleted media, however, the overexpressing cell lines were no longer viable. Interestingly, a myeloid cell line constitutively expressing Id also was inviable after growth factor deprivation (Kreider et al. 1992). This suggests that down-regulation of Id may be required for cells to enter a quiescent state before the onset of differentiation. Consistent with this hypothesis is the fact that several different cell types down-regulate Id as they enter $G_{0}$ even in the presence of high mitogen, that is, murine erythroleukemia (MEL) cells treated with dimethylsulfoxide (DMSO), F9 cells treated with retinoic acid (Benezra et al. 1990; Sun et al. 1991), and low density myoblasts treated with transforming growth-factor- $\beta$ (TGF- $\beta$ ) (Zentella and Massague 1992).

When $\mathrm{C} 2 \mathrm{C} 12$ cells overexpresing Id were selected for their ability to grow after long-term serial passage, only 1 clone in 20 survived [C2E : $\operatorname{Id}(S)]$. Interestingly, in the proliferating state, this clone had only a marginal in- crease in steady-state Id mRNA relative to the parental line, suggesting that the window of Id mRNA levels that can be tolerated in continuously growing cultures is extremely narrow. In C2E : Id(S) cells after $16 \mathrm{hr}$ of serum deprivation, there is a fivefold increase in exogenous Id mRNA and a dramatic block of myogenesis, as assayed by the formation of mature myotubes and the expression of MLC mRNA. After $48 \mathrm{hr}$, however, these cells do convert to muscle at near normal frequencies despite the presence of Id mRNA.

This apparent discrepancy is resolved by an analysis of Id protein levels. When $\mathrm{C} 2 \mathrm{C} 12$ cell expressing LTR-Id were stained with an anti-Id antibody, those cells that were beginning to express MHC consistently showed undetectable Id staining in the nucleus. MHC-negative cells in the same field showed prominent Id staining in the nucleus with characteristic nucleolar exclusion. This is not the result of antibody exclusion in the MHCpositive nuclei, as parallel preparations showed prominent MyoD nuclear staining in these cells (data not shown). This result was confirmed in an independent assay in which Id protein levels in the C2E : Id population were measured by direct immunoprecipitation. Thus, Id protein levels are not only controlled transcriptionally by serum withdrawal but also post-transcriptionally. It is possible that such post-transcriptional control serves to speed the response of the cell to serum deprivation: After cessation of Id mRNA synthesis, clearing of the endogenous Id protein pools would be required to initiate the differentiation response. A similar effect has been observed in myoblasts constitutively expressing $\mathrm{v}$-jun mRNA, as myotubes that form in these cells have lost Jun nuclear staining (Grossi et al. 1991; Su et al. 1991). Also, as constitutive expression of c-myc mRNA has been shown to block myogenesis to varying extents under different experimental conditions (Schneider et al. 1987; Miner and Wold 1991), it will be of interest to see whether levels of Myc protein in the nuclei of these cells determine the differentiated state of the cell.

In this report we have presented in vivo data supporting the idea that Id inhibits muscle differentiation by competing with $\mathrm{MyoD}$ for its transcriptional cofactors, the $\mathrm{E}$ proteins. This model provides a molecular description of the commitment and differention process in muscle: A cell is committed to the muscle differentiation pathway if it expresses MyoD; however, the committed muscle precursor cell cannot differentiate until the cell receives a second environmental cue, which serves to down-regulate the levels of Id protein (and, perhaps, myc, jun, and fos as well). This allows MyoD to pair with its transcriptional cofactors, the E proteins, and activate expression of the muscle structural genes. These secondary controls on MyoD protein activity might serve to prevent myogenesis until conditions are appropriate, for example, to prevent myogenesis during the period of myoblast migration from the somites to the limb bud or to prevent myogenesis in satellite precursor cells. We suspect that while the down-regulation of Id protein levels is necessary for muscle differentiation, it is probably not 
sufficient. For example, TGF- $\beta$ treatment and overexpression of c-myc prevent muscle differentiation /Vaidya et al. 1989; Miner and Wold 1991) despite the downregulation of Id mRNA (Brennan and Olson 1991; Miner and Wold 1991). Other control points in the regulation of the differentiation process such as post-translational modification of the $\mathrm{E}$ proteins or the muscle regulatory proteins are also likely.

The down-regulation of MyoD steady-state mRNA levels in myoblasts constitutively expressing Id raises the intriguing possibility that Id may, under certain conditions, directly regulate the expression of positively acting bHLH proteins. The recent observation that there is mutually exclusive expression of Id and the myogenic factors in the somites of mouse embryos supports this hypothesis (Y. Wang, R. Benezra, and D. Sassoon, in prep.). We imagine that the relatively weak interaction of Id and MyoD (Benezra et al. 1990; Sun et al. 1991) might be overcome by high levels of Id expression and that this may have the effect of breaking the MyoD /and/ or myogenin) autoregulatory loops. Lower levels of Id expression might selectively inhibit the E proteins owing to the relatively high affinity of these two proteins. Such hierarchical interactions between various HLH proteins could serve to further expand the functional repertoire of these proteins.

\section{Materials and methods}

\section{Cell lines and transfections}

All cells were maintained in Dulbecco's modified Eagle medium (DMEM) plus $15 \%$ fetal calf serum (FCS). P2 aza-myoblasts were established as described (Davis et al. 1987). C2C12 myoblasts were provided by Helen Blau (Stanford University, CA). Stable transformants of the $\mathrm{C} 2 \mathrm{C} 12$ cell line were generated by electroporation. Briefly, $10^{6}$ cells were harvested at $50 \%$ confluence and suspended in $0.8 \mathrm{ml}$ of phosphate-buffered saline (PBS). The cells were transferred to electroporation cuvettes $[0.4$ $\mathrm{mm}$, Bio-Rad) and mixed with $1 \mathrm{mg}$ of pRSV-neo linearized with BamHI and either $10 \mu \mathrm{g}$ of pEMSV-scribe (Davis et al. 1987) or $\mathrm{pE}: \mathrm{Id}(\mathrm{S})$ (Benezra et al. 1990) linearized with KpnI. The cells were electroporated by use of the Bio-Rad Gene Pulser at $300 \mathrm{~V}$ and $950 \mu \mathrm{F}$ and then placed immediately into DMEM plus $15 \%$ FCS. After $48 \mathrm{hr}$, the cells were switched to media containing $0.5 \mathrm{mg} / \mathrm{ml}$ of G418 (GIBCO). Colonies were isolated after 10 days.

\section{Northern analysis}

Total cytoplasmic RNA was prepared as described (Favaloro et al. 1980). Five micrograms of cytoplasmic RNA was tested by Northern analysis as described (Benezra et al. 1990). The MyoD and MLC probes (Davis et al. 1987) and the Id probe (Benezra et al. 1990) have been described previously. The E2A probe was generated by polymerase chain reaction (PCR) amplification of a mouse E2A cDNA clone (kindly provided by M. Krause, Fred Hutchinson Cancer Center) by use of primers that flanked the bHLH domain.

\section{Cell fractionation and immunoprecipitation}

Undifferentiated P2 myoblasts (40\% confluent) and P2 myotubes $148 \mathrm{hr}$ in DMEM, $10 \mathrm{mg} / \mathrm{ml}$ of insulin, and $5 \mathrm{mg} / \mathrm{ml}$ of transferrin postconfluence) were metabolically labeled in 150$\mathrm{mm}$ tissue culture dishes by first rinsing the plates three times in PBS and then incubating for $4 \mathrm{hr}$ at $37^{\circ} \mathrm{C}$ in DMEM minus methionine (GIBCO), 2 mM glutamine, $50 \mathrm{~mm}$ HEPES (pH 7.5), and $1.5 \mathrm{mCi}$ of $\left[{ }^{35} \mathrm{~S}\right]$ TRANS label (New England Nuclear). The myoblast labeling mixure was supplemented with $5 \%$ dialyzed FCS. The label was removed, and the plates were rinsed twice in PBS before adding PBS, $5 \mathrm{~mm}$ EDTA, and $100 \mathrm{mg} / \mathrm{ml}$ of aprotinin. After rocking at room temperature for $10 \mathrm{~min}$, the cells were dislodged from the plate by tapping and harvested into 1.5-ml Eppendorf tubes. The cells were centrifuged for $10 \mathrm{sec}$ at $10,000 \mathrm{~g}$, supernatants were discarded, and cells were resuspended in $400 \mu \mathrm{l}$ of homogenization buffer [(hb) $0.3 \mathrm{M}$ sucrose, $10 \mathrm{~mm}$ Tris $8.0,10 \mathrm{~mm} \mathrm{NaCl}, 3 \mathrm{mM} \mathrm{MgCl}_{2}, 0.5 \% \mathrm{NP}-40,100$ $\mu \mathrm{g} / \mathrm{ml}$ of aprotinin] by pipetting. The cells were vortexed briefly, set on ice for $2 \mathrm{~min}$, and centrifuged at $10,000 \mathrm{~g}$ for 10 sec. The supernatant ( $10 \mathrm{mM} \mathrm{NaCl}$ fraction) was mixed with an equal volume of antibody buffer [(Ab) $20 \mathrm{~mm}$ Tris $(\mathrm{pH} 7.5), 50$ $\mathrm{mM} \mathrm{NaCl}, 0.5 \% \mathrm{NP}-40,0.5 \%$ sodium deoxycholate, $0.5 \% \mathrm{SDS}$, $1 \mathrm{~mm}$ EDTA, $100 \mu \mathrm{g} / \mathrm{ml}$ of aprotinin]. The nuclei were then sequentially extracted with $\mathrm{hb}+300 \mathrm{mM} \mathrm{NaCl}$ and $\mathrm{hb}+500$ $\mathrm{mM} \mathrm{NaCl}$, as described above, and the supernatants were mixed with equal volumes of $\mathrm{Ab}$. The final nuclear pellet was resuspended in $400 \mu \mathrm{l}$ of hb $+500 \mathrm{~mm} \mathrm{NaCl}$, mixed with $400 \mu \mathrm{l}$ of $\mathrm{Ab}$, and sonicated briefly to reduce the viscosity. The myoblast and myotube samples were divided into three and two equal aliquots, respectively, and volumes were normalized to $400 \mu \mathrm{l}$ total before adding the appropriate antiserum (see below). The samples were rocked for $4 \mathrm{hr}$ at $4^{\circ} \mathrm{C}$ and mixed with $15 \mu \mathrm{l}$ of packed protein A-agarose beads (Repligen). After rocking for an additional hr, the beads were washed four times in $\mathrm{Ab}$, resuspended in $25 \mu \mathrm{l}$ of an SDS sample buffer, and boiled for $10 \mathrm{~min}$. The beads were pelleted, and the supernatants were run on a $15 \%$ discontinuous SDS-polyacrylamide gel. Anti-E12 antisera was a gift from C. Murre (University of California, San Diego), and the MyoD antisera used has been described (Tapscott et al. 1988).

Antibodies to Id were generated by using a GEX-Id fusion protein. Briefly, a BamHI-EcoRI fragment of pMH18DR (Benezra et al. 1990) containing the entire coding region of Id was subcloned into BamHI/EcoRI-cut pGEX-2T (Smith and Johnson 1988). The resulting plasmid (pGEX-2T-Id) was transformed into $\mathrm{HB101}$ cells, and a saturated culture was grown in $\mathrm{LB}+100 \mu \mathrm{g} / \mathrm{ml}$ of ampicillin (LBamp). For preparative inductions, the saturated cultures were diluted $1 / 30$ in fresh LBamp (typically $100 \mathrm{ml}$ final volume) and grown at $37^{\circ} \mathrm{C}$ for $1 \mathrm{hr}$, and isopropyl- $\beta$-D-thiogalactopyranoside (IPTG) was added to a final concentration of $100 \mu \mathrm{M}$. Cultures were grown for another $3 \mathrm{hr}$ at $37^{\circ} \mathrm{C}$, cells were harvested at $2000 \mathrm{~g}$, and pellets were resuspended first in $1 \mathrm{ml}$ of $\mathrm{LB}$, followed by $5 \mathrm{ml}$ of $2 \times$ sample buffer. The preparative SDS-gel protocol and immunization procedure have been described previously (Tapscott et al. 1988).

Coimmunoprecipitations were performed by use of the 10 $\mathrm{mM} \mathrm{NaCl}$ fraction of $\left[{ }^{35} \mathrm{~S}\right]$ methionine-labeled $\mathrm{P} 2$ myoblasts described above before the addition of $\mathrm{Ab}$ buffer. This fraction (from $3 \times 150-\mathrm{mm}$ plates of proliferating myoblasts) was split into five equal fractions, and the volumes made up to $\sim 500 \mu \mathrm{l}$ with $\mathrm{hb}+10 \mathrm{~mm} \mathrm{NaCl}$. Preimmune E12 antiserum $(1.5 \mu \mathrm{l}$; a gift from C. Murre) was added to samples 1 and 3, and anti-E12 antiserum $(1.5 \mu \mathrm{l})$ was added to samples 2,4 , and 5 . The samples were rocked at $4^{\circ} \mathrm{C}$ for $4 \mathrm{hr}, 30 \mu$ l of protein A-agarose beads was added, and the samples were rocked for an additional hour. The beads were pelleted at $10,000 \mathrm{~g}$ for $10 \mathrm{sec}$ and washed three times in $0.8 \mathrm{ml}$ of $\mathrm{hb}+10 \mathrm{mM} \mathrm{NaCl}$. Samples 1 and 2 were resuspended in $25 \mu \mathrm{l}$ of SDS-sample buffer and saved at $-20^{\circ} \mathrm{C}$. HLH complexes were disrupted by adding $400 \mu$ l of RIPA buffer (Har- 
low and Lane 1988) to the beads of samples 3,4 , and 5, and the samples were rocked at $4^{\circ} \mathrm{C}$ for $1 \mathrm{hr}$. After spinning at $10,000 \mathrm{~g}$ for $10 \mathrm{sec}$, the supernatants were decanted and transferred to new Eppendorf tubes. Five microliters of preimmune Id antiserum was added to sample 4 , and $5 \mu$ l of anti-Id antiserum was added to samples 3 and 5 . Fifteen microliters of packed protein A-agarose beads was added to each sample, and all were rocked at $4^{\circ} \mathrm{C}$ for $3 \mathrm{hr}$. The beads were washed three times in $0.8 \mathrm{ml}$ of RIPA buffer, $25 \mu \mathrm{l}$ of SDS sample buffer was added to the pelleted beads, and all samples were heated to $95^{\circ} \mathrm{C}$ for $5 \mathrm{~min}$. Samples 1-5 were analyzed on a $15 \%$ discontinuous SDS-polyacrylamide gel and correspond to lanes $1-5$ of Figure 1B.

To estimate the molar ratio of E2A protein to Id in the immunoprecipitated material, the two major bands in Figure 1b, lane 2, migrating at $68 \mathrm{kD}$ were assumed to be the major E2A gene products. This is based on a comparison with the preimmune precipitate and the apparent molecular mass of the proteins immunoprecipitated with this antiserum under highstringency conditions (defined below). The ratio of the integrated intensity of the E2A bands in lane 2 to that of the Id bands in lane 5 was measured by densitometric scanning on a LKB Ultroscan XL laser densitometer. Values were corrected for the relative methionine content of E2A versus Id protein and the relative exposure time.

Immunoprecipitations from $\mathrm{C} 2 \mathrm{C} 12$ cells were performed by first metabolically labeling the cells for $16 \mathrm{hr}$ as described above. After rinsing the cells twice with PBS, total cell lysates were generated by adding $1.5 \mathrm{ml}$ of cold $\mathrm{Ab}$ buffer to $10-\mathrm{cm}$ plates and scraping into plastic tubes. The lysates were sonicated briefly to reduce the viscosity and centrifuged at $10,000 \mathrm{~g}$ for $5 \mathrm{~min}$, and the supernatants were transferred to a new tube. Preimmune and immune antisera were added to $2 \times 10^{7} \mathrm{cpm}$ of total cellular protein at a $1 / 250$ dilution. The samples were rocked at $4^{\circ} \mathrm{C}$ for $4 \mathrm{hr}$. Packed protein A-agarose beads $(25 \mu \mathrm{l})$ were added, and the samples were rocked for an additional hr at $4^{\circ} \mathrm{C}$. The beads were pelleted at $10,000 \mathrm{~g}$ for $10 \mathrm{sec}$ and washed four times in cold Ab buffer. The final pellet was resuspended in 25 $\mathrm{ml}$ of an SDS-sample buffer and analyzed on a $15 \%$ discontinuous SDS gel.

Competitions were performed by incubating the anti-Id antiserum with purified GEX or GEX-Id $(1 \mu \mathrm{g}$ of protein/ $\mu \mathrm{l}$ antiserum) overnight at $4^{\circ} \mathrm{C}$. The competed antiserum was then used at $1 / 100$ dilution as described above. Preclearing $\mathrm{C} 2 \mathrm{C} 12 \mathrm{ly}$ sates was performed by adding $1 / 100$ dilution of preimmune sera and protein $\mathrm{A}$-agarose beads $(70 \mu \mathrm{l}$ packed beads $/ \mathrm{ml})$ to the lysates and rocking at $4^{\circ} \mathrm{C}$ for $2 \mathrm{hr}$. Supernatants were recovered by centrifugation and used directly in immunoprecipitations as described above.

\section{Whole-cell extracts and EMSA}

Proliferating C3H10T1/2 and P2 myoblasts and differentiated P2 myotubes were grown and harvested as described above. To normalize samples for the number of nuclei, cell pellets from one to two $150-\mathrm{mm}$ plates were resuspended in $500 \mu \mathrm{l}$ of PBS, and $50 \mu \mathrm{l}$ of each was diluted into $250 \mu \mathrm{l}$ of hb and incubated on ice for $2 \mathrm{~min}$. After vortexing gently, the nuclei in each sample were counted. The remaining cell suspension in PBS was centrifuged at $10,000 \mathrm{~g}$, and the cells were resuspended in $\mathrm{hb}+400$ $\mathrm{mM} \mathrm{NaCl}$ so that the resulting concentration of nuclei was $5 \times 10^{6} / \mathrm{ml}$. After incubation on ice for $2 \mathrm{~min}$ and a brief vortex, the nuclei were pelleted, and the supernatants were decanted and made $20 \%$ in glycerol. Extracts were stored at $-70^{\circ} \mathrm{C}$.

Electrophoretic mobility shift assays (EMSAs) were performed by using a ${ }^{32} \mathrm{P}$-labeled 25-bp oligonucleotide containing the MyoD-binding site of the MCK enhancer (Lassar et al. 1989).
Typically, in a $20-\mu 1$ reaction the components were $20 \mathrm{mM}$ HEPES ( $\mathrm{pH} 7.6$ ), $50 \mathrm{~mm} \mathrm{KCl}, 1 \mathrm{~mm}$ dithiothreitol, $1 \mathrm{~mm}$ EDTA, $5 \%$ glycerol, the indicated amount of double-stranded poly[d(IC) (10-160 ng), and $2 \mu \mathrm{l}$ of the above extracts. Binding reactions were carried out at room temperature for $15 \mathrm{~min}$, immediately loaded onto a $5 \%$ polyacrylamide gel $(40: 1.33$ acrylamide/bisacrylamide), and run in $1 \times$ TBE buffer (50 $\mathrm{mm}$ Tris-base, $50 \mathrm{~mm}$ boric acid, $1 \mathrm{~mm}$ EDTA) for $2.5-3.5 \mathrm{hr}$ at $8 \mathrm{~V} / \mathrm{cm}$. Gels were dried and autoradiographed.

Double-shift experiments were performed by incubating $2 \mu l$ of the appropriate whole-cell lysate with radiolabeled DNA + $40 \mathrm{ng}$ of poly[d(I-C)], as described above, for $15 \mathrm{~min}$ at room temperature. The mixture was then placed on ice for 5 min before the addition of $6 \mathrm{ml}$ of the appropriate IgG fraction $(\sim 0.2 \mu \mathrm{g} / \mu \mathrm{l})$. After $15 \mathrm{~min}$ on ice, the mixture was loaded onto a $5 \%$ polyacrylamide gel (see above) and run at $8 \mathrm{~V} / \mathrm{cm}$ and $4^{\circ} \mathrm{C}$ for 6-8 hr.

\section{Immunofluorescence}

C2E : Id cells were grown to $75 \%$ confluence and switched to serum-free media containing insulin and transferrin (see above) for 16-20 hr. Cells were fixed for $10 \mathrm{~min}$ in PBS with $2 \%$ paraformaldehyde, permeabilized in PBS with $0.25 \%$ Triton $\mathrm{X}-100$, and stained with a $1 / 250$ dilution of a rabbit anti-Id antiserum and a $1 / 5$ dilution of a monoclonal antibody to MHC (MF20; Bader et al. 1982). The secondary antibodies used were a $1 / 500$ dilution of rhodamine-conjugated donkey antiserum to rabbit IgG and a $1 / 500$ dilution of fluorescein conjugated goat antiserum to mouse IgG. Competition assays were performed by first preincubating the anti-Id antiserum with a 1/100 dilution of lysates from bacterial cells expressing either GEX alone or GEX-Id.

\section{Acknowledgments}

We thank Susan Pesce for expert technical assistance. In addition, we are grateful to C. Murre, A. Voronova, and T. Kadesch for the anti-E12 antisera. R.B. thanks Jill, Noah, and Stella B. for their kind support. H.W. is an investigator of the Howard Hughes Medical Institute.

The publication costs of this article were defrayed in part by payment of page charges. This article must therefore be hereby marked "advertisement" in accordance with 18 USC section 1734 solely to indicate this fact.

\section{References}

Alonso, L.G. and A. Garcia-Bellido. 1986. Genetic analysis of hairy-wing muations. Wilhelm Roux's Arch. Dev. Biol. 195: $259-264$.

1988. Extramachrochaete, a trans-acting gene of the achaete-scute complex of Drosophila involved in cell communication. Wilhelm Roux's Arch. Dev. Biol. 197: 328-338.

Bader, D.M., T. Masaki, and D.A. Fischman. 1982. Immunochemical analysis of myosin heavy chain during avian myogenesis in vivo and in vitro. J. Cell Biol. 95: 763-770.

Benezra, R., R.L. Davis, D. Lockshon, D.L. Turner, and H. Weintraub. 1990. The protein Id: A negative regulator of helixloop-helix DNA binding proteins. Cell 61: 49-59.

Blackwell, T.K. and H. Weintraub. 1990. Differences and similarities in DNA-binding preferences of MyoD and E2A protein complexes revealed by binding site selection. Science 250: 1104-1110.

Brennan, T.J. and E.N. Olson. 1991. TGF- $\beta$ represses the actions of myogenin through a mechanism independent of DNA 
binding. Proc. Natl. Acad. Sci. 88: 3822-3826.

Buskin, J.N. and S.D. Hauschka. 1989. Identification of a myocyte nuclear factor which binds to the muscle-specific enhancer of the muscle creatine kinase gene. Mol. Cell. Biol. 9: $2627-2640$.

Cabrera, C.V., A. Martinez-Arias, and M. Bate. 1987. The expression of three members of the achaete-scute complex correlates with neuroblast segregation in Drosophila. Cell 50: $425-433$.

Caudy, M., E.H. Grell, C. Dambly-Chaudiere, A. Ghysen, L.Y. Jan, and Y.N. Jan. 1988. The maternal sex-determination gene daughterless has zygotic activity necessary for the formation of peripheral neurons in Drosophila. Genes \& Dev. 2: $843-852$.

Christy, B.A., L.K. Sanders, L.F. Lau, N.G. Copeland, N.A. Jenkins, and D. Nathans. 1991. An Id-related helix-loop-helix protein encoded by a growth factor inducible gene. Proc. Natl. Acad. Sci. 88: 1815-1819.

Cordle, S.R., E. Henderson, H. Masuoka, P.A. Weil, and R. Stein. 1991. Pancreatic $\beta$-cell-type-specific transcription of the insulin gene is mediated by basic-helix-loop-helix DNA-binding proteins. Mol. Cell. Biol. 11: 1734-1738.

Crescenzi, M., T.P. Fleming, A.B. Lassar, H. Weintraub, and S.A. Aaronson. 1990. MyoD induces growth arrest independent of differentiation in normal and transformed cells. Proc. Natl. Acad. Sci. 87: 8442-8446.

Dambly-Chaudiere, C., A. Ghysen, L.Y. Jan, and Y.N. Jan. 1988. The determination of sense organs in Drosophila: Interaction of scute with daughterless. Wilhelm Roux's Arch. Dev. Biol. 197: 419-423.

Davis, R.L., H. Weintraub, and A.B. Lassar. 1987. Expression of a single transfected cDNA converts fibroblasts to myoblasts. Cell 51: 987-1000.

Davis, R.L., P.-F. Cheng, A.B. Lassar, and H. Weintraub. 1990. The MyoD DNA binding domain contains a recognition code for muscle-specific gene activation. Cell 60: 733-746.

Ellis, H.M., D.R. Spann, and J.W. Posakony. 1990. extramachrochaete, a negative regulator of sensory organ development in Drosophila, defines a new class of helix-loop-helix proteins. Cell 61: 27-38

Favaloro, J., R. Freisman, and R. Kamen. 1980. Transcription maps of polyoma virus-specific RNA: Analysis by two-dimensional nuclease $\mathrm{S} 1$ gel mapping. Methods Enzymol. 65: 718-749.

Garrell, J. and J. Modolell. 1990. The Drosophila extramachrochaete locus, an antagonist of proneural genes that, like these genes, encodes a helix-loop-helix protein. Cell 61: 3948.

Gonzalez, F., S. Romani, P. Cubas, J. Modolell, and S. Campuzano. 1989. Molecular analysis of the asense gene, a member of the achaete-scute complex of Drosophila melanogaster, and its novel role in optic lobe development. $E M B O$ J. 8: 3553-3562.

Grossi, M., A. Calconi, and F. Tato. 1991. v-jun oncogene prevents terminal differentiation and suppresses muscle-specific gene expression in ASV-17 infected muscle cells. Oncogene 6: 1767-1773.

Harlow, E. and D. Lane. 1988. Antibodies: A laboratory manual. Cold Spring Harbor Laboratory, Cold Spring Harbor, New York.

Henthorn, P., M. Kiledjian, and T. Kadesch. 1990. Two distinct transcription factors that bind the immunoglobulin $\mathrm{mE5} /$ kE2 motif. Science 247: 467-470.

Kreider, B., R. Benezra, G. Roverea, and T. Kadesch. 1992. Inhibition of myeloid differentiation by the helix-loop-helix protein Id. Science 255: 1700-1702.
Lassar, A.B., J.N. Buskin, D. Lockshon, R.L. Davis, S. Apone, S.D. Hauschka, and H. Weintraub. 1989. MyoD is a sequence-specific DNA binding protein requiring a region of myc homology to bind to the muscle creatine kinase enhancer. Cell 58: 823-831.

Lassar, A.B., R.L. Davis, W.E. Wright, T. Kadesch, C. Murre, A. Voronova, D. Baltimore, and H. Weintraub. 1991. Functional activity of myogenic HLH proteins requires hetero-oligomerization with E12/E47-like proteins in vivo. Cell 66: 305315.

Miner, J.H. and B. Wold. 1991. c-myc inhibition of MyoD and myogenin-initiated myogenic differentiation. Mol. Cell. Biol. 11: 2842-2851.

Moscoso del Prado, J. and A. Garcia-Bellido. 1984. Genetic regulation of the Achaete-scute complex of Drosophila melanogaster. Wilhelm Roux's Arch. Dev. Biol. 193: 242-245.

Murre, C., P.S. McCaw, and D. Baltimore. 1989a. A new DNA binding and dimerization motif in immunoglobulin enhancer binding, daughterless, MyoD, and myc proteins. Cell 56: 777-783.

Murre, C., P.S. McCaw, H. Vassin, M. Caudy, L.Y. Jan, Y.N. Jan, C.V. Cabrera, J.N. Buskin, S.D. Hauschka, A.B. Lassar, H. Weintraub, and D. Baltimore. 1989b. Interactions between heterologous helix-loop-helix proteins generate complexes that bind specifically to a common DNA sequence. Cell 58: 537-544.

Parkhurst, S.M., D. Bopp, and D. Ish-Horowicz. 1991. X : A ratio, the primary sex-determining signal in Drosophila, is transduced by helix-loop-helix proteins. Cell 63: 1179-1191.

Pongubala, J.M.R. and M.L. Atchison. 1991. Functional characterization of the developmentally controlled immunoglobulin kappa 3' enhancer: Regulation by Id, a repressor of helixloop-helix transcription factors. Mol. Cell. Biol. 11: 10401047.

Ron, D. and J.F. Habener. 1992. CHOP, a novel developmentally regulated nuclear protein that dimerizes with transcription factors C/EBP and LAP and functions as a dominant-negative inhibitor of gene transcription. Genes \& Dev. 6: 439453.

Rosenthal, N. 1992. The myosin light chain 1/3 locus: A model for developmental control of skeletal muscle differentiation. In Gene expression in neuromuscular development led. $\mathrm{H}$. Blau, T. Kelly, and B. Paterson). Raven Press, New York. (In press.)

Schlissel, M., A. Voronova, and D. Baltimore. 1991. Helix-loophelix transcription factor E47 activates germ-line immunoglobulin heavy-chain gene transcription and rearrangement in a pre-T-cell line. Genes \& Dev. 5: 1367-1376.

Schneider, M.D., M.B. Perryman, P.A. Payne, G. Spizz, R. Roberts, and E.N. Olson. 1987. Autonomous expression of c-myc in $\mathrm{BC} 3 \mathrm{H} 1$ cells partially inhibits but does not prevent myogenic differentiation. Mol. Cell. Biol. 7: 1973-1977.

Smith, D.B. and K.S. Johnson. 1988. Single-step purification of polypeptides expressed in Escherichia coli as fusions with glutathione S-transferase. Gene 67: 31-40.

Sorrentino, V., R. Pepperkok, R.L. Davis, W. Ansorge, and L. Philipson. 1990. Cell proliferation inhibited by MyoD1 independently of myogenic differentiation. Nature 345: 813815.

Su, H., T.J. Bos, F.S. Monteclaro, and P.K. Vogt. 1991. Jun inhibits myogenic differentiation. Oncogene 6: 1759-1766.

Sun, X.-H., N.G. Copeland, N.A. Jenkins, and D. Baltimore. 1991. Id proteins Idl and Id2 selectively inhibit DNA binding by one class of helix-loop-helix proteins. Mol. Cell. Biol. 11: 5603-5611.

Tapscott, S.J., R.L. Davis, M.J. Thayer, P.F. Cheng, H. Wein- 
traub, and A.B. Lassar. 1988. Myo D: A nuclear phosphoprotein requiring a myc homology region to convert fibroblasts to myoblasts. Science 242: 405-411.

Treacy, M.N., X. He, and M.G. Rosenfeld. 1991. I-POU: A POUdomain protein that inhibits neuron-specific gene activation. Nature 350: 554-555.

Vaidya, T.B., S.J. Rhodes, E.J. Taparowsky, and S.F. Konieczny. 1989. Fibroblast growth factor and transforming growth factor beta repress transcription of the myogenic regulatory gene MyoD1. Mol. Cell. Biol. 9(8): 3576-3579.

Van Doren, M., H.M. Ellis, and J.W. Posakony. 1991. The Drosophila extramachrochaetae protein antagonizes sequence-specific DNA binding by daughterless/achaete-scute protein complexes. Development 113: 245-255.

Villares, R. and C.V. Cabrera. 1987. The achaete-scute gene complex of D. melanogaster: Conserved domains in a subset of genes required for neurogenesis and their homology to myc. Cell 50: 415-424.

Wilson, R.B., M. Kiledjian, C-P. Shen, R. Benezra, P. Zwollo, S.M. Dymecki, S.V. Desiderio, and T. Kadesch. 1991. Repression of immunoglobulin enhancers by the helix-loop-helix protein Id: Implications for B lymphoid development. Mol. Cell. Biol. 11: 6185-6191.

Zentella, A. and J. Massague. 1992. TGF- $\beta$ induces myoblast differentiation in the presence of mitogens. Proc. Natl. Acad. Sci. 89: 5176-5180. 


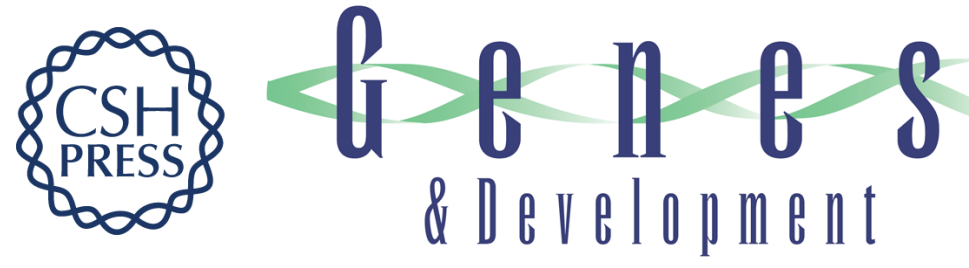

\section{Overexpression of Id protein inhibits the muscle differentiation program: in vivo association of Id with E2A proteins.}

Y Jen, $\mathrm{H}$ Weintraub and R Benezra

Genes Dev. 1992, 6:

Access the most recent version at doi:10.1101/gad.6.8.1466

References This article cites 44 articles, 21 of which can be accessed free at: http://genesdev.cshlp.org/content/6/8/1466.full.html\#ref-list-1

License

Email Alerting

Service

Receive free email alerts when new articles cite this article - sign up in the box at the top right corner of the article or click here.

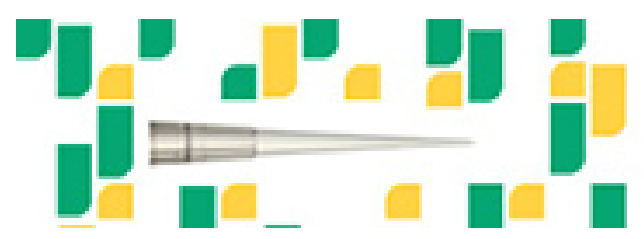

Focused on your science. 